\title{
Ethnologies
}

\section{Jews, Museums, and National Identities}

\section{Reesa Greenberg}

Volume 24, numéro 2, 2002

Musées

Museums

URI : https://id.erudit.org/iderudit/006642ar

DOI : https://doi.org/10.7202/006642ar

Aller au sommaire du numéro

Éditeur(s)

Association Canadienne d'Ethnologie et de Folklore

ISSN

1481-5974 (imprimé)

1708-0401 (numérique)

Découvrir la revue

Citer cet article

Greenberg, R. (2002). Jews, Museums, and National Identities. Ethnologies, 24(2), 125-137. https://doi.org/10.7202/006642ar
Résumé de l'article

Les musées, et en particulier les musées d'ethnographie, constituent des lieux paradigmatiques pour tester les limites de la tolérance en ce qui concerne les cultures minoritaires (tolérance de celles-ci, envers celles-ci, ou à l'intérieur d'elles-mêmes). En considérant quelques musées juifs en Europe, j'examine quatre variables interdépendantes en tant qu'indices de tolérance :1) l'intégration d'un musée dans l'ensemble de la culture ; 2) l'inclusion de différents types ethniques juifs : 3 ) la représentation des femmes ; et 4) la réponse au génocide.
Ce document est protégé par la loi sur le droit d'auteur. L'utilisation des services d'Érudit (y compris la reproduction) est assujettie à sa politique d'utilisation que vous pouvez consulter en ligne.

https://apropos.erudit.org/fr/usagers/politique-dutilisation/ 


\title{
Jews, Museums, and National Identities
}

\author{
Reesa Greenberg \\ Adjunct Professor \\ Concordia University, Montréal and York University, Toronto
}

The antidote to hatred in the heart, the source of violence, is tolerance (The Dalai Lama).

The existence of a number of new European Jewish museums offers an opportunity to examine how tolerance for others - Jews for different kinds of Jews, Jews for non-Jews, and non-Jews for Jews - is enacted at particular historical moments. Tolerance has different meanings. The most common interpretation is recognition of the existence of the Other. A more active form of tolerance is inviting the Other into one's sphere, making literal and psychic space for the Other, in some way, consciously incorporating the Other. The more active form of tolerance involves an ongoing and ever-changing mixture of negotiation, co-habitation and integration. It also involves a willingness to abandon myths of selfrepresentation and the construction of the Other as enemy, evil, or extraneous ${ }^{1}$.

Three variables determine whether and how the presence of the Other manifests. The first is time or timing, a concept related to distress tolerance or the degree of distress people can bear in a given moment ${ }^{2}$. An inter-related component is the relationship of tolerance to terror

1. Various versions of this essay were presented at Museums and National Identity, Jewish Museum, Berlin, October, 7, 2001 and La Représentation de Soi et de L'Autre dans les Musées, Musée de la Civilisation, Québec, February 19, 2002. Parts of the text have been published in Dolff-Bonëkamper and Van Voolen (2000) and in Hornstein and Jacobowitz (2002).

2. The concept of distress tolerance was developed by Marsha Linehan in her work with Borderline Personality disorders (1993). 
and trauma, two features of any post-war Jewish museum. A third aspect of tolerance is the role of culture - national, religious, or political in setting or pushing limits. When a culture is unable to question its concepts of tolerance, its museums recreate dominant discourses or repeat the tropes of a seemingly known storyline.

Museums, particularly ethnographic museums, are paradigmatic sites for testing the limits of tolerance of, for and within, minority cultures. In my discussion of european Jewish museums in Europe, I examine four inter-related variables as indices of tolerance: 1) a museum's integration into the culture at large; 2) the inclusion of various Jewish ethnic and racial types; 3) the representation of women; and 4) the response to genocide. Although my examples are geographically specific, the model can be used for analyzing Jewish museums elsewhere and, with modifications, for non-Jewish museums as well.

Since the mid-1980s, important Jewish museums have opened or re-opened in capital cities of five European nations: The Jewish Historical Museum in Amsterdam (1987), the Jewish Museum in Frankfurt (1988), The Jewish Museum in Vienna (1995), The Museum of Jewish Art and History in Paris (1998) and, most recently, the Jewish Museum in Berlin (2001). With the exception of Paris, Jewish museums existed in each of these cities prior to World War II and were forcibly closed by the Nazis. Although none are Holocaust Museums, their existence, collections, story lines, and display aesthetics are inextricable from the events and aftermath of the Holocaust, a history of intolerance that resulted in six million murders and great pain for millions more. Post-war European Jewish museums usually contain two components, both inextricable from the Holocaust. The first is a collection of Judaic ritual objects reassembled or amassed after the Holocaust either as a form of commemoration for the dead or as testimony to the vibrancy of a lost Jewish culture. The second component is a representation of some form of Jewish history, biblical, religious, or local, usually one which gives prominence to the emancipation of Jews in the nineteenth century and the subsequent terror and trauma of the Holocaust.

The very existence of so many new Jewish museums in Europe can be seen as a sign of tolerance on the part of the countries in which they are located. Because of recent State and local government funding, Jewish museums have never been as large or as grand or as integrated into national museum or educational culture. Each of these ethnographic 
museums is part of a national, provincial or municipal museum network rather than private. The public performance of museal integration enacted by these museums, however, may be at the expense of Jewish participation or visibility in a wider sphere.

Take for example, the Musée d'art et d'histoire du judaïsme in Paris, a "palace" museum located in the renovated Hôtel de Saint-Aignan. The very name of the museum differentiates it from Jewish museums in countries such as Holland or Germany, which are categorized solely as history museums. Using the designation "art" aligns the new museum with a long and proud Parisian art museum history and, at the same time, refers to The Museum of Jewish Art founded in Paris in 1948 to preserve the lost culture of Central European Jewry. The collection from the earlier museum has been incorporated into the new institution as has the Judaïca collection from the Musée Cluny, a national museum also in Paris, inaugurated in 1843 when the State acquired the Medieval art collection of Alexandre du Sommerard. At the Musée Cluny, the Judaïca collection was just that, one collection among others. It was based on the 1890 donation of 149 items from the Isaac Strauss collection purchased by Baron Nathaniel Rothschild and exhibited as art objects in a room bearing the Baron's name.

The underlying concept of the collection policy at the new Musee d'art et d'histoire du judaisme is centralization. Between 1988 and 1998, a variety of liturgical objects, archeological finds, architectural structures, textiles, manuscripts, artworks, and photographs were amassed from various private collections and French museums, including the Centre Georges Pompidou, in and outside Paris. The result is un grand musée but the removal of art objects associated with Jews and Judaism from other museums removes Jews and Judaica from sight or reduces their presence in non-Jewish cultural insititutions. Both the Jewish community and the State have shifted how Jews and Judaica are exhibited in France. The creation of a large Jewish museum in Paris at this time marks the end of the integrationist period inaugurated with Napoleon's emancipation of French Jews ${ }^{3}$.

The segregation/integration dilemna is part of Jewish museum history, an index of how tolerated a Jewish community feels or the manner in which the State wishes to portray tolerance. For example, the oldest

3. For more detailed histories of Le musée d'art et d'histoire du judaïsme, consult www.mahj.org. 
Jewish museum was initiated in Vienna in 1891 as an independent entity in its own space, but when the Jewish Historical Museum in Amsterdam was founded in 1932, it was located in a room in one of the old city towers, The Waagge, the same building as The Amsterdam Historical Museum. In Amsterdam, the Jewish museum presented Jewish life as part of both Netherlandish and Jewish history (see Bendt 1991: 72-74 for a comparative history).

Closed by the Nazis in 1940, the museum reopened in 1955 and only when the Amsterdam Historical Museum moved to larger quarters in 1975 was the Jewish Historical Museum on its own, albeit still in space associated with Amsterdam - it now filled The Waagge. In 1987, the Jewish Historical Museum moved into five deconsecrated seventeenth and eighteenth century synagogues in the former Jewish quarter and aligned itself with a network of museums and memorials sites linked to the Holocaust such as the Hollandische Schouwberg, a former collecting site for Jewish deportees, and the Anne Frank House. The Jewish Historical Museum's architectural links are now Jewish, not Dutch, despite its State status. Although a small display on Jews and Amsterdam was added to current municipal museum exhibitions and the displays at the Jewish Historical Museum repeatedly invoke a Dutch context, the cessation of co-habitation is indicative of the end of an era when tolerance was performed by sharing space ${ }^{4}$.

A similar situation of separating Jewish history from municipal or national history exists in Berlin. Initially, the expansion of the three rooms of the post-war Jewish section of the Berlin Municipal Museum entailed the construction of a new building by Daniel Libeskind, a third of which would be devoted to a larger display of Jews and Berlin. Libeskind's design was predicated on an underground attachment to the Berlin museum but eventually, after much heated debate, the Municipal Museum left its eighteenth century building and the Jewish Museum took over this space as well as all of Libeskind's building. What began as a conciliatory gesture of tolerance and inclusion on the part of the city after the War became a tug of war throughout the 1980s and

4. Peggy Phelan (1993) pioneered discussions about performativity and culture. Barbara Kirshenblatt-Gimblett discusses how Jews "performed culture" in world fair exhibitions by choosing portrayals that ranged from the ethnographic to ones in which Jews were seen as part of the history of religion (1998: 79-130, chapter "Exhibiting Jews"). 
1990s. The end result is an enormous Jewish Museum with 350,000 artifacts which tells the story of Jews in Germany rather than the original conception of a municipal museum with a large Jewish section. The refusal of Jews to be integrated into a larger history can be seen as a form of resentment, a renunciation of being defined by or in relation to the Other, and a lack of tolerance for illusions of tolerance on the part of the Other.

In Paris, the construction of a Jewish museum of similar critical mass corresponds to a period in history when the demographics of the French Jewish population have changed and substantial numbers of French Jews do not wish to assimilate into French culture. The Jewish population of Paris is now over fifty per cent Sephardic, many of whom came to France after the 1950s from North Africa as pieds-noirs seeking a more tolerant nation-state when France liberated the colonized Muslim countries in which they lived. Like Orthodox Ashkenaz Jews, many North African Jews do not wish to integrate or assimilate invisibly into French culture but be accepted for what they are - Jews. Their physical features often make "passing" as non-Jews or being mistaken for the Other more difficult as does their insistence on a sacred as well as secular definition of Judaism.

France's Musée d'art et d'histoire du judaïsme is expansive in its geographic and ethnic coverage, more of a pan-European/Mediterranean Jewish museum, a feature conveyed by its substantial collection of Sephardica and the amount of space devoted to its display ${ }^{5}$. Costumes, jewelry, liturgical objects, photographs, and paintings of and from the Middle East and North Africa are magnificently exhibited in great numbers in several designated galleries that seem to form a museum within a museum located at the end of the top floor. The artifacts underline racial and religious differences within Judaism, a theme that European Jewish museums which confine their mandate to local or national Jewish history barely broach.

Not all Jewish groups that came to France are given such prominence. Jews from Eastern Europe who emigrated are presented obliquely as part of the last two sections of the permanent displays. The largest is devoted to pre-World War I, School of Paris artists, the most well known being Marc Chagall, Chaim Soutine, Jacques Lipschitz,

5. Marie Chabchay, the first curator of Le musée d'Art juif de Paris, began the collection of Sephardica. 
Ossip Zadkine, and Chana Orloff. The second area in which Eastern European Jews figure is the Holocaust section where their status as refugees, not French citizens, is emphasized. In both instances, the presentations are reductive and stereotypical. There is the foreign artist who escapes traditional Jewish life whether in the East or in Paris and there is the foreign, working class victim of National Socialism and the Vichy regime who did not survive World War II. These are the only possible roles the museum allows Eastern European Jews and, in both instances, they are positioned as Other, tolerated but apart.

This limitation on roles is also problematic in representations of women. There are more images of Jewish women in the Sephardica section of the museum than anywhere else. Their presentation primarily as exotica rather than integral personages in Jewish life and history is disturbing to contemporary feminist eyes. A label states that Muslim women were forbidden to model for French and foreign artists, implying that, because Jewish women did, they symbolize an undifferentiated Oriental Other. The number of elaborate dresses on display enhances the sense that Sephardic women are seen as ornamental rather instrumental ${ }^{6}$. No labels expand the roles of Sephardic women and there is no presence of the strong tradition of Parisian feminism from the 1970's in which a number of Jews such as Hélène Cixous remain prominent. Contemporaneous Jewish museums in Amsterdam, Vienna and Berlin present women very differently. Women are actively tolerated as equal, an index of change in a religion where the daily morning prayers recited by Orthodox and Conservative Jewish men still include a statement thanking God "for not making me a woman."

In Vienna, the American artist Nancy Spero was commissioned to create an installation for the walls of the inner courtyard of the museum. Spero worked with three themes in her Remembrance/Renewal cycle: Jewish rituals, Viennese social and cultural life before World War II, and the Holocaust. In all three sectors, images of women predominate, resulting in what amounts to a history of Jewish women. Spero's compositional technique of scattering her stamped images intermittently over a large surface embodies the spaces and gaps in all histories, and is particularly effective in histories such as those of the Holocaust or Jewish women which are histories of absences and breaks in chronology. There is no comparable history of Jewish men in the museum. Their relative

6. See Dubuc (2002) for a detailed discussion of clothing in museums. 
absence underscores the radical revisioning of gender in Vienna's Jewish Museum.

By contrast, at the Jewish Museum in Berlin, within the thematic of Two Millennia of German Jewish History devised under the directorship of the American Michael Blumenthal, the presentation of Jewish women is integrated into a traditional unfolding of history. A concerted effort has been made to include images of Jewish women and ritual practices pertaining only to them early in the chronology, probably inspired by Spero's practice of researching illustrated manuscripts for images of Jewish women. In the Jewish museum in Berlin, what is distinctive is the concentration given to a specific woman in early German Jewish history, Gluckl van Hameln, and the device of explaining the seventeenth century perspective of women through Gluckl's experience as wife, mother and business woman. It is rare to have documents written by women from this era and Gluckl's Memoir was reprinted many times. Various versions of Gluckl's Memoir, prints and documents dating from her time period as well as wall texts and videos expanding on her views allot her, and by extension, Jewish women more actual space early on in the chronology than is the norm in most Jewish museums. A small display centered on an enlarged photograph of Bertha Pappenheim, dressed as Gluckl bridges the shift from more family-centred roles for Jewish women in the seventeenth century to twentieth century roles of activism and philanthropy. Later in the museum route, objects associated with Jewish women such as the Frauen Bibel (women's bible) and portraits of Jewish women have been included, often in ways that draw attention to them. For example, in the single framing of individual portraits of Abraham, Nathan and Dorothea Mendelsohn, Dorothea's colour image stands out placed between the black and white renderings of the men.

The emphasis on stories at the Jewish museum in Berlin is one of the structures through which the museum creates processes of identification on the part of museum visitors. The Berlin museum is more personal than the museum in Paris where processes of identification and projection occur around art objects. In Berlin, individual stories on the two main floors of the museum's displays are combined in a chronological structure arranged in a rambling linear path with one entrance and one exit. Despite the individual stories, though, the overarching narrative in the museum is one of intolerance resulting in 
the mass murders of Jews. This narrative structure typifies Jewish museums in Germanic cultures.

The way the Holocaust is represented is an index of how tolerated a Jewish population feels at the time and in the place the display is designed. For example, at the1988 Jewish Museum in Frankfurt, the representation of Jewish life in that city begins and ends with images of violence against Jews. Visitors first see a replica of the Midieval ghetto paired with a film about murders of Jews in the Middle Ages and end the parcours in two rooms representing the Holocaust. The last images a visitor to the museum sees are photographs of liberated concentration camp survivors, American and Israeli flags, and a memorial wall listing the names of Frankfurt citizens deported to their death. The message, underscored by the cage-like structure dominating the first Holocaust room, the dark walls, the sombre lighting, and the absence of German flags is that there is no hope for Jewish life in a country where there is so much intolerance.

In Germanic Jewish museums, the identification process for Jews is inextricable from the Holocaust. At the Jewish Museum in Berlin, the trajectory of the visit begins and ends with the Holocaust. Even if there is a section portraying life for Jews in Germany after the Holocaust and the recently immigrated Russian Jewish community, because of the parcours, visitors must re-enter the Holocaust display in order to reach the stairway that leads to the exit. The last images and text panel visitors see in the permanent display speak of emigration. And as (Jewish) visitors re-enter the underground zones of the building, making their way back through Libeskind's three, tilted-wall axes - Exile, the Holocaust and Continuity - before leaving through the doors of what was once the Berlin Municipal Museum, they are again reminded of how little tolerance Jews in Europe received and how unstable their life there remains?

The Jewish Museums in Frankfurt and Berlin are not alone in focusing on the intolerance of non-Jews for Jews. The 1995 Jewish Museum in Vienna may look lighter and brighter but here the Holocaust is implied on all three floors of the permanent exhibitions. The ground floor courtyard gallery contains a single, long vitrine exhibiting a small part

7. Sabine Offe (2000) has written the most comprehensive analysis of German Jewish Museums. Ruth Gruber (2002) also discusses some smaller German Jewish Museums. 
of the 10,000 item collection Max Berger assembled after the war as a memorial to his dead family. Spero's amalgam of found, reworked period images is placed near the vitrine, at eye level, incorporating photographs of the arrest of Viennese Jews, Viennese Jews forced to wash the streets on their knees, a destroyed synagogue and the Stars of David Jews were made to wear by the Nazis. The second floor tells a synoptic history of Viennese Jewry using holographic images of objects in the collection to convey the ephemerality of history and the sense of loss after the Holocaust. On the third floor, the bulk of the collection is displayed as a storage area, referencing both a museum work space and a depot for possessions stolen from Jews during the Holocaust. The various modes of highly stylized display for the museum's collections call attention to its corpus, as a way of referring to the missing corpses of the Holocaust. The relative emptiness of the museum, its frustration of nostalgia and sentimentality and its refusal to portray contemporary Jewish life in Vienna keep the focus on a history of intolerance.

When the Jewish Museum in Vienna reopened in 1995, chief curator Felicitas Heimann-Jelineck stated: "Above all, the main interest of a post-1945 European Jewish Museum should be to motivate its visitors to ask themselves the right questions..." (Heimann-Jelineck and Sulzenbacher 1996: 129) ${ }^{8}$. Heimann-Jelineck's adoption of an interrogative rather than a declarative mode of visual discourse enabled a questioning of the fundamental concept of a post-Holocaust Jewish museum as a monument to survival. The overwhelming sadness conveyed by the displays in the museum is an index of how low the distress level on the part of the Jewish community in Vienna is to the threat of future intolerance.

The numbers of Jews from Amsterdam and Paris murdered during the Holocaust was as great, sometimes proportionately more so than in German cities, yet the representation of the Holocaust in Jewish museums in those cities is not as pervasive as in Germanic Jewish museums. In the Amsterdam Jewish Historical Museum, the Holocaust section is located early on in the displays, approximately one sixteenth of the way through a non-chronological arrangement of the permanent exhibitions, the third of a five part section portraying Jewish identity.

8. Also see Gruber (2002: 174-179) for a thoughtful discussion of the aesthetics of the Jewish Museum in Vienna and the difficulties of presenting unusual forms of display. 
As one works one's way through the museum the terror, the trauma and the intolerance of the Holocaust is easily forgotten. Throughout the museum, visitors are reminded of the history of Dutch religious tolerance, a history that enabled Jews expelled from Spain in 1492 to practice their religion safely in Holland for centuries. The very location of the museum in five converted synagogues and the first display, an eighteenth century ark designed to hold the Torah placed in the middle of two embracing "arms" imprinted with portraits of Dutch Jews placed over typical, Dutch landscapes, set the museum's tone. The Holocaust or underside of Dutch religious tolerance is represented directly behind the ark where the visual vocabulary of the newspaper-shaped vitrines conveys the factual nature of the period documents exhibited.

In the Jewish Historical Museum in Amsterdam, the perception and portrayal of terror and trauma against Jews is not as overwhelming as Jewish museums in Germany or Austria. A national history and mythology of tolerance conditions the Jewish community to expect acceptance and to resist an interpretation of the Holocaust in which Dutch betrayal plays a significant role. Seventy-five percent of Holland's Jewish community did not survive World War II. Tellingly two photographs, one of German planes with parachuters and another of the Americans liberating Holland, portray Holland as a victim of foreign forces and a country that could only be saved by an even more powerful foreign ally. Jewish tolerance of Dutch collaboration and intolerance leads to a more hopeful representation of the Holocaust, one in which contemporary images of Jews and Judaism are integrated throughout the museum.

At the Musée d'art et d'histoire du judaïsme in Paris, the Holocaust section literally hangs in the air. The open, free floating landing of the staircase that leads visitors to the ground floor at the end of the permanent exhibition to the spaces currently used for temporary exhibitions is the area where the Holocaust is represented. As with many museal representations of the Holocaust, there is a factual section and an area with artwork. Here, the story of the Holocaust as designed by Nous travaillons ensemble with documents provided by the Museum is muted, told in enlargements of black and white period photographs and documents with explanatory wall labels recounting a minimum of detail. A permanent installation, Les habitants de l'hôtel de Saint-Aignan en 1939, by Christian Boltanski at the bottom of the stairs 
commemorates Jews who lived in the Hôtel de Saint-Aignan before the war but did not return.

The Holocaust is presented as an elegant art installation, an aside, literally suspended in time and space, unintegrated, an aberration. As in Holland, the national myths of tolerance and equality are hard to dislodge both in and outside the Jewish community. There is no history of national culpability, no history of collaboration, no history of complicity. Unlike the Jewish Museum in Amsterdam, the permanent displays end with the Holocaust. The inclusion of a post-Holocaust permanent display in Paris would open questions of intolerance amongst Jews and the place of Israel in French foreign relations. These are only hinted at in five temporary photography exhibitions at the end of the parcours.

The museum's avoidance of Post-Holocaust Israeli politics creates a fictive united front among French Jews. Many fled the growing intolerance for Jews in Muslim lands after the founding of the State of Israel in 1948. They now live in a nation often more sympathetic to Arab countries than Israel and among Ashkenaz Jews who view them as Other. The museum's reluctance to portray the complex relationships of post-war Jews in France and their equally complex relations to Israel speaks to the discomfort of portraying any sign of intolerance, secular or sacred, within Jewish communities. Perhaps that is why images of Sephardic Jews in the museum's permanent collection belong to the pre-State of Israel era and depict Jews from other countries. Perhaps too that is why Sophie Calle's Erouv, a photographic installation presenting the Orthodox practice of cordoning off an area in Israel for the Sabbath, is positioned early on, out of chronological order, in the section of the museum where sacred Jewish history is portrayed, rather than with the other French, post-Holocaust artworks9.

In discussions of ethnography and identity politics, it is now an axiom that representations of the Self are inextricable from representations of the Other. I want to suggest that representations of the Other are inextricable from representations of the Other. The relationship between Self and Other is more than a dyad, more than a

9. Erouv alludes to the politics of tolerance and intolerance between more and less religious Jews and the power of Israel's Orthodox minority to determine both sacred and secular Israeli life. In 2001, Orthodox Jews in Montréal won a court case enabling them to mark off an area of Outrement with string. 
duality, especially when various, sometimes conflicting, Selves and Others are represented. That is what makes embodying and enacting tolerance, both in and outside the museum, such a daunting challenge. In national museums, those challenges are compounded because nation states and their citizens often depend on simplistic definitions of the Self and the Other ${ }^{10}$.

10. In the summer of 2002, the Musée d'art et d'histoire du judaïsme relocated the Holocaust section. It is now found immediately to the left of the main entrance, in a small space at the bottom of the stairs that lead to the beginning of the museum's parcours. Even in this location the Holocaust is treated as separate from the rest of Jewish history in France, quickly forgotten as visitors become immersed in the upper floor galleries and their magnificent displays. 


\section{References}

Bendt, V. 1991. "Museum Amsterdam/Jüdisches Museum Berlin". Museums Journal III, 5 Jahrg.(Juli): 72-74.

Dubuc, Élise. 2002. Vêtement, corps, musée: L'objet-sujet ou le Patrimoine incarné. Université de Montréal, doctoral dissertation, unpublished.

Greenberg, Reesa. 2000. "Die Ästhetik des Traumas: Zur Darstellung des Holocaust in Jüdischen Historischen Museen". In DolffBonëkamper, Gabi and Edward Van Voolen (eds.), Denkmale und kulturelles Gedächtnis nach dem Ende der Ost-West-Konfrontation. Berlin, Jovis, Akademie der Künste: 227-238.

—. 2002. "The Jewish Museum Vienna: A Holographic Paradigm for History and the Holocaust" in Hornstein, Shelley and Florence Jacobowitz (eds.), Afterimage: Remembrance and the Holocaust, University of Indiana Press: 135-151.

Gruber, Ruth. 2002. Virtually Jewish; Reinventing Jewish Culture in Europe. Los Angeles / London, Berkeley, University of California Press.

Heimann-Jelineck, Felicitas. 1996. "Memoria, Intelligentia, Providentia". In Heimann-Jelineck, Felicitas and Hannes Sulzenbacher (eds.), Jewish Museum Vienna. Vienna, Jewish Museum of the City of Vienna.

Kirshenblatt-Gimblett, Barbara. 1998. Destination Culture: Tourism, Museums and Heritage. Berkeley and Los Angeles, University of California Press.

Linehan, Marsha. 1993. Skills Training Manual for Treating Borderline Personality Disorder. Guilford, New York.

Offe, Sabine. 2000. Ausstellungen, Einstellungen, Entstellungen: Jüdische Museen in Deutschland und Österreich. Berlin, Philo.

Phelan, Peggy. 1993. Unmarked:the politics of performance. London and New York, Routledge.

www.mahj.org. 